\title{
A Cryptand-Type Aluminum Tris(salophen) Complex: Synthesis, Characterization, and Cell Imaging Application
}

\author{
Hao-Yan Yin ${ }^{1}$, Jing Lai ${ }^{1,2}$, Juan Tang ${ }^{1}$, Yanli Shang ${ }^{2, *}$ and Jun-Long Zhang ${ }^{1, *} \mathbb{C}$ \\ 1 Beijing National Laboratory for Molecular Sciences, \\ State Key Laboratory of Rare Earth Materials Chemistry and Applications, \\ College of Chemistry and Molecular Engineering, Peking University, Beijing 100871, China; \\ yinhaoyan@pku.edu.cn (H.-Y.Y.); xjdbxq@126.com (J.L.); tangjuan@pku.edu.cn (J.T.) \\ 2 College of Chemistry and Environmental Science, \\ Key Laboratory of Analytical Science and Technology of Hebei Province, Hebei University, \\ Baoding 071002, China \\ * $\quad$ Correspondence: shyl@iccas.ac.cn (Y.S.); zhangjunlong@pku.edu.cn (J.-L.Z.); Tel.: +86-010-6276-7034 (J.-L.Z.)
}

Received: 30 November 2017; Accepted: 19 January 2018; Published: 24 January 2018

\begin{abstract}
Metal salen/salophen complexes have been used as fluorescent probes for cell imaging with various metal centers. Herein we synthesized cryptand-type aluminum salophen complexes $\mathrm{LAl}_{3}$ and the corresponding mononuclear compound LAl. X-ray crystal diffraction verifies the cryptand-type structure of $\mathrm{LAl}_{3}$ with $C_{3 h}$ symmetry. Both $\mathrm{LAl}_{3}$ and $\mathrm{LAl}$ show moderate green fluorescence with quantum yields of 0.17 and 0.05 , respectively. The hydrophilic and cationic nature of these aluminum salophen complexes renders them enhanced cellular uptake. Both complexes are internalized into cells by energy-dependent pathways and they distribute in lysosomal organelles.
\end{abstract}

Keywords: schiff-base complexes; aluminum; optical properties; cell imaging

\section{Introduction}

Metal salen/salophen complexes have been widely studied in catalysis [1-4] and supramolecular chemistry [5-7], and in recent years they have also attracted a great deal of attention for their biological applications as fluorescent probes and prodrugs [8-16]. In our group, a series of $\mathrm{Zn}$ salen/salophen complexes have been reported as fluorescent probes for cell imaging even with super-resolution, with multiple functions such as intracellular reactive oxygen species, monitoring the lipid droplets and autophagy processes [17-23]. However, Zn salen complexes tend to aggregate through the axial intermolecular interactions between the $\mathrm{Zn}$ center and the phenolic oxygen of another molecule, especially in non-coordinating solvents [24-29]. The aggregation not only weakens fluorescence intensity, but also influences the cellular uptake pathway and subcellular localization [30]. To minimize the effect of the intermolecular $\mathrm{Zn}$... O interactions, several approaches have been reported, such as adding an axial ligand, introducing positive charges in the ligand, and increasing the number of sterically hindered substituents [31]. This also includes a series of trinuclear Zn salophen complexes with cryptand-type structures, which could reduce the intermolecular $\mathrm{Zn} \cdots \mathrm{O}$ interactions [32].

However, the trinuclear $\mathrm{Zn}$ salophen complexes suffer from little intracellular fluorescence signal, probably due to low cellular uptake arising from the hydrophobicity and neutral form and thus could not be directly used as cell imaging probes. To enhance the cellular uptake, we envisioned to use the main group element $\mathrm{Al}(3+)$ cation for (1) form the cation complexes; (2) closed shell structure similar to $\mathrm{Zn}^{2+}$; and (3) Lewis acid reactivity. These features render $\mathrm{Al}$ salen/salophen complexes better cell imaging probes than Zn complexes [33,34]. Previously, we demonstrated that 
monomeric [AlSalen] ${ }^{+} \mathrm{Cl}^{-}$displayed higher sensitivity and stronger intracellular fluorescence in monitoring intracellular microvisicosity than $\mathrm{Zn}$ analogue. In this work, we synthesized the trinuclear aluminum salophen complex $\mathrm{LAl}_{3}$ and the corresponding mononuclear complex $\mathrm{LAl}$ and performed live cell imaging experiments to reveal the ability of $\mathrm{LAl}_{3}$ as a fluorescent probe, which highlights the importance of choice of metal ion in design of metal probes.

\section{Results and Discussion}

\subsection{Synthesis and Characterization}

Mononuclear salophen ligand and Al salophen complexes were synthesized according to the reported methods [35-40]. Salicylaldehyde and $o$-phenylenediamine were refluxed in ethanol for $16 \mathrm{~h}$ to give the orange salophen ligand. The reaction of salophen ligand with aluminum chloride in acetonitrile afforded the target mononuclear complex LAl. More importantly, we synthesized the trinuclear aluminum salophen complex $\mathrm{LAl}_{3}$ to study the potential synergistic effect (Figure 1). Trinuclear cryptand-type salophen ligand was prepared according to the procedure reported by T. Nabeshima [41], and $\mathrm{LAl}_{3}$ was obtained by stirring ligand and aluminum chloride in refluxing acetonitrile for $24 \mathrm{~h}$. The axial chloride was replaced by fluoride to get $\mathrm{LAl}_{3}-\mathrm{F}$, which was used for crystal growth.

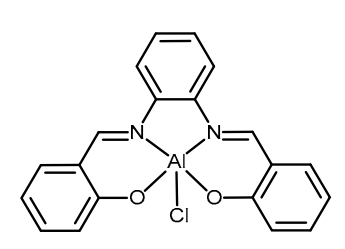

LAl

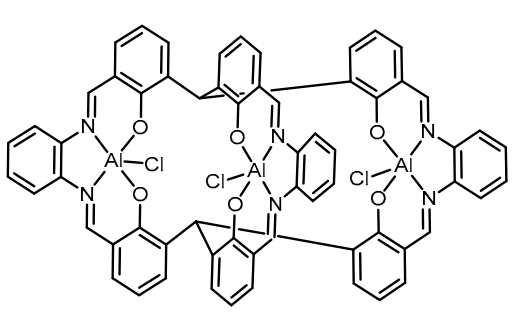

$\mathrm{LAl}_{3}$

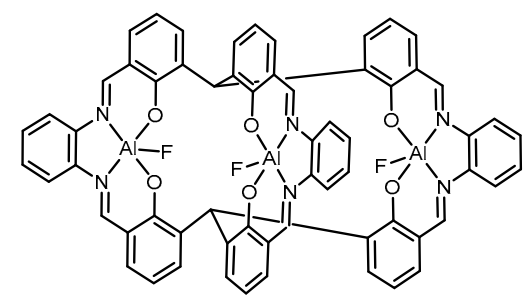

$\mathrm{LAl}_{3}-\mathrm{F}$

Figure 1. Chemical structures of the $\mathrm{Al}$ salophen complexes.

The three compounds were characterized by ${ }^{1} \mathrm{H}$ NMR, ESI-MS, and IR spectroscopies. ${ }^{1} \mathrm{H}-\mathrm{NMR}$ spectra in DMSO-d6 show good resolution of the proton signals. Aromatic and imine protons in $\mathrm{LAl}_{3}$ display nearly same chemical shifts with the mononuclear LAl, revealing the use of cryptand-like tri-salophen ligand has little effect to the conjugated system in the salophen moieties. The disappearance of an aromatic peak at $\delta=7.68$ and the emergence of a single peak at $\delta=8.27$ corresponding to the methenyl protons are strong proofs supporting the cryptand-type structure of $\mathrm{LAl}_{3}$. IR spectra show characteristic $\mathrm{C}=\mathrm{N}$ vibration $\left(1625,1620 \mathrm{~cm}^{-1}\right)$ of metal salophen complexes. The ESI mass spectra of the mononuclear and trinuclear Al salophen complexes show main peaks corresponding to $\mathrm{m} / \mathrm{z}$ peak at 341.0866 and 1191.1954, respectively. The accurate exact mass and the successful assignment of ${ }^{1} \mathrm{H}$ NMR signals ensure that the cryptand structure of $\mathrm{LAl}_{3}$ is right.

To further confirm the structure of $\mathrm{LAl}_{3}$, we grew a single crystal (CCDC 1814298) suitable for $\mathrm{X}$-ray structure analysis via the diffusion of $\mathrm{N}$-hexane to a methanol/toluene mixed solution of $\mathrm{LAl}_{3}-\mathrm{F}$. The detailed parameters are listed in Table S1. As shown in Figure 2, each $\mathrm{Al}^{3+}$ shows octahedral coordination geometry, with a fluorinion and a methanol molecule as the axial ligand. $\mathrm{Al}^{3+}$ only $0.109 \AA$ above the $\mathrm{N}_{2} \mathrm{O}_{2}$ plane and the angles between each two $\mathrm{N}_{2} \mathrm{O}_{2}$ planes are near $60^{\circ}$, indicating the $C_{3}$ symmetry of the molecule. Given that there is a symmetry plane perpendicular to the $C_{3}$ axial, the $\mathrm{LAl}_{3}$ molecule belongs to $C_{3 h}$ point group. Each salophen moiety shows great distortion, with the angle between two phenyl planes being near $58.57^{\circ}$, larger than that in the crystal of mononuclear LAl reported by Darensbourg et al. [35]. The octahedral coordination geometry as well as the distortion of salophen moieties inhibit the aggregation of the molecules. 


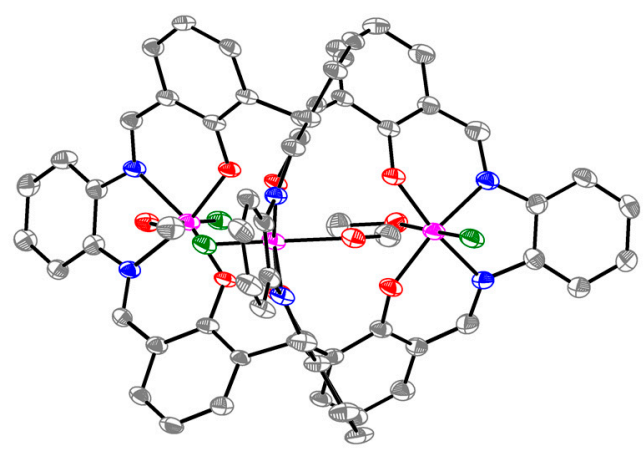

(a)

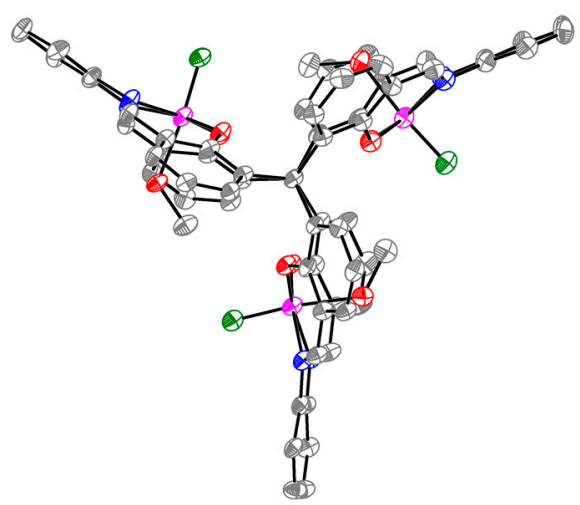

(b)

Figure 2. An ORTEP diagram of the single crystal X-ray structure of $\mathrm{LAl}_{3}$ : (a) top view and (b) side view. The thermal ellipsoids are scaled to the $50 \%$ probability level. Carbon atoms are depicted in grey, oxygen in red, nitrogen in blue, fluorine in green, and aluminum in pink.

\subsection{UV-Vis and Fluorescent Spectra}

The absorption spectra of two Al salophen complexes in DMSO are shown in the Figure 3. The two main absorption bands at near 300 and $400 \mathrm{~nm}$ can be assigned to salophen-centered $\pi-\pi^{*}$ transitions. Different from the previously reported $\mathrm{Zn}$ salen complexes [17,21,31], no intramolecular charge-transfer transition bands between $500-600 \mathrm{~nm}$ is observed for there is no " $\mathrm{D}-\pi-\mathrm{A}$ " structure in the salophen ligands. The absorption peaks of $\mathrm{LAl}_{3}$ red-shifts ca. $20 \mathrm{~nm}$ compared to LAl. Besides, the extinction coefficient of $\mathrm{LAl}_{3}$ is obviously larger than $\mathrm{LAl}$ because of the increasing number of the salophen chromophores in one molecule. (Table 1)

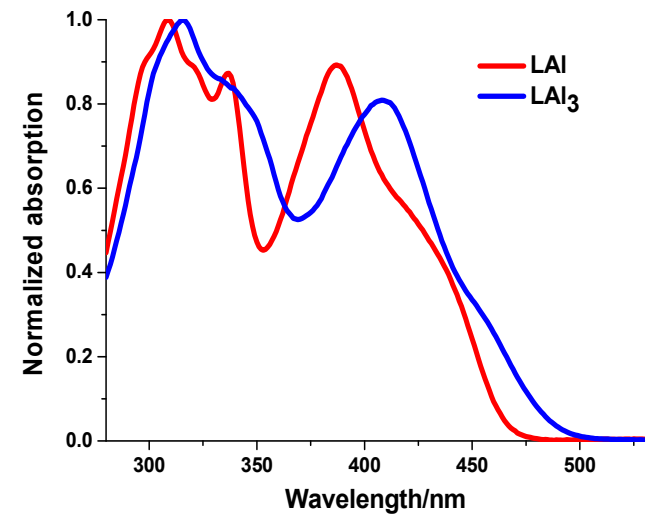

(a)

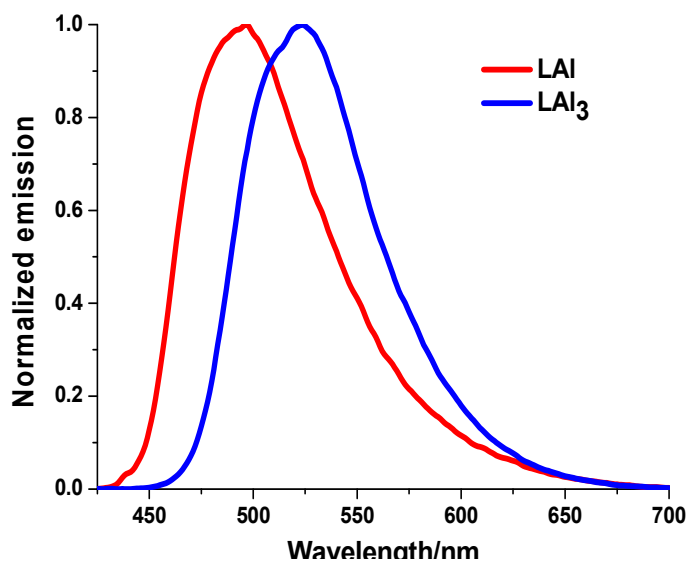

(b)

Figure 3. UV-Vis and fluorescence spectra of the Al salophen complexes. (a) Normalized UV-Vis absorbance spectra in DMSO at $298 \mathrm{~K}$ of LAl and $\mathrm{LAl}_{3} ;(\mathbf{b})$ Normalized emission spectra in DMSO at $298 \mathrm{~K}$ of $\mathrm{LAl}$ and $\mathrm{LAl}_{3}\left(\lambda_{\mathrm{ex}}=396 \mathrm{~nm}\right)$.

Emission spectra were recorded to investigate the excited state properties of two Al salophen complexes. (Figure 3) $\mathrm{LAl}$ and $\mathrm{LAl}_{3}$ show similar single emission bands with emission maxima at 500 and $523 \mathrm{~nm}$, respectively. The large Stokes shift (ca. $115 \mathrm{~nm}$ ) of $\mathrm{LAl}_{3}$ is consistent with the previous report of cryptand-type $\mathrm{Zn}$ salophen complexes. Fluorescence lifetime of the two complexes were monitored at their emission maxima, and fluorescence quantum yields $( \pm 10 \%)$ were determined as 0.054 and 0.17 for $\mathrm{LAl}$ and $\mathrm{LAl}_{3}$ in $\mathrm{DMSO}$, using quinine sulfate $\left(\Phi_{\mathrm{f}}=0.54\right.$ in $\left.0.1 \mathrm{~N} \mathrm{H}_{2} \mathrm{SO}_{4}\right)$ as standard. The longer lifetime and higher fluorescence quantum yield of $\mathrm{LAl}_{3}$ can be attributed to its high 
structure rigidity. The fluorescence quantum yields of Al salophen complexes were only slightly larger than corresponding Zn complexes reported by us previously, indicating that similar closed-shell metal centers show little effect to the fluorescence quantum yield of salophen complexes.

Table 1. Photophysical properties of $\mathrm{Al}$ salophen complexes ${ }^{1}$.

\begin{tabular}{ccccc}
\hline Compound & $\lambda_{\text {abs }}(\log \varepsilon) / \mathbf{n m}\left(\log \mathbf{M}^{-\mathbf{1}} \mathbf{c m}^{-\mathbf{1}}\right)^{\mathbf{2}}$ & $\lambda_{\text {em }} / \mathbf{n m}^{\mathbf{3}}$ & $\boldsymbol{\tau} / \mathbf{n s}$ & $\boldsymbol{\Phi}^{\mathbf{4}}$ \\
\hline $\mathrm{LAl}$ & $308(4.12), 337(4.06), 387(4.07)$ & 500 & 0.58 & 0.054 \\
$\mathrm{LAl}_{3}$ & $315(4.76), 341(4.67), 408(4.66)$ & 523 & 2.90 & 0.17
\end{tabular}

${ }^{1}$ All data was determined in DMSO. ${ }^{2}$ Wavelength of absorption peaks and the corresponding extinction coefficients.

${ }^{3}$ Wavelength of fluorescence emission peaks. ${ }^{4}$ Fluorescence quantum yield with the quinine sulfate $\left(0.1 \mathrm{~N} \mathrm{H}_{2} \mathrm{SO}_{4}\right.$,

$\Phi=0.54)$ as standard, the uncertainty is $\pm 10 \%$.

\subsection{Lipophilicity}

Molecular lipophilicity is an important parameter affecting cellular uptake pathway and subcellular localization. To evaluate lipophilicity of the two complexes, we measured the $N$-octanol-water partition coefficient ( $\log P$, Table 2) according to Leo's method [42]. Compared to $\mathrm{LAl}$, trinuclear $\mathrm{LAl}_{3}$ showed larger $\log P$. This increase of the hydrophobicity might be due to the cage-like structure of the cryptand-type ligand, exposing the hydrophobic groups and protecting the hydrophilic metal centers inside the cage. Log $P$ of Al complexes are significantly smaller compared to corresponding Zn complexes $(\log P>1.0)$, indicating $\mathrm{Al}$ salophen complexes are much more hydrophilic, which might be due to the cationic nature of the $\mathrm{Al}$ salophen complexes.

Table 2. Octanol-water partition coefficients $(\log P)$ of $\mathrm{Al}$ salophen complexes.

\begin{tabular}{cc}
\hline Compound & $\log \boldsymbol{P}$ \\
\hline $\mathrm{LAl}$ & 0.10 \\
$\mathrm{LAl}_{3}$ & 0.18 \\
\hline
\end{tabular}

\subsection{Cell Imaging}

In order to demonstrate different cellular behaviors of two Al salophen complexes, the cytotoxicity of the two compounds was evaluated by CCK-8 assay after $24 \mathrm{~h}$ incubation of the complexes with HeLa cells firstly (Figure 4). The result showed that in a concentration of $5 \mu \mathrm{M}$, the high cell viability up to $95 \%$ indicated low cytotoxicity. We chose this concentration for the subsequent imaging experiments.

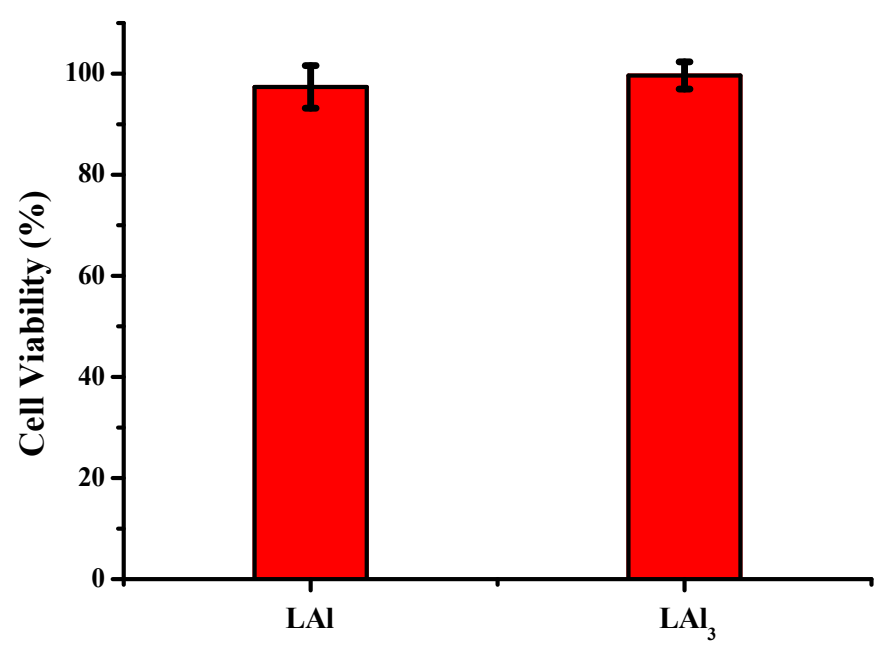

Figure 4. Cytotoxicity of the two indicated complexes toward HeLa cells using CCK-8 assay. HeLa cells were incubated with $5 \mu \mathrm{M}$ dye for $24 \mathrm{~h}$ in complete media (Mean $\pm \mathrm{SD}$ ). 
Intracellular fluorescence of the two complexes in HeLa cells was studied by laser scanning confocal microscopy. As shown in Figure 5, incubation with $5 \mu \mathrm{M} \mathrm{LAl}$ or $\mathrm{LAl}_{3}$ for $12 \mathrm{~h}$ led to green punctuate luminescence recorded in a perinuclear pattern. The corresponding Zn complexes showed almost invisible intracellular fluorescence under the same incubation condition, reflecting the relatively higher cellular uptake levels of Al salophens than that of $\mathrm{Zn}$ salophens. We ascribed this difference to the positive central charge of Al salophens, which allows Al salophens to traverse the negatively charged cellular membrane more easily than $\mathrm{Zn}$ salophens, driven by the membrane potential.

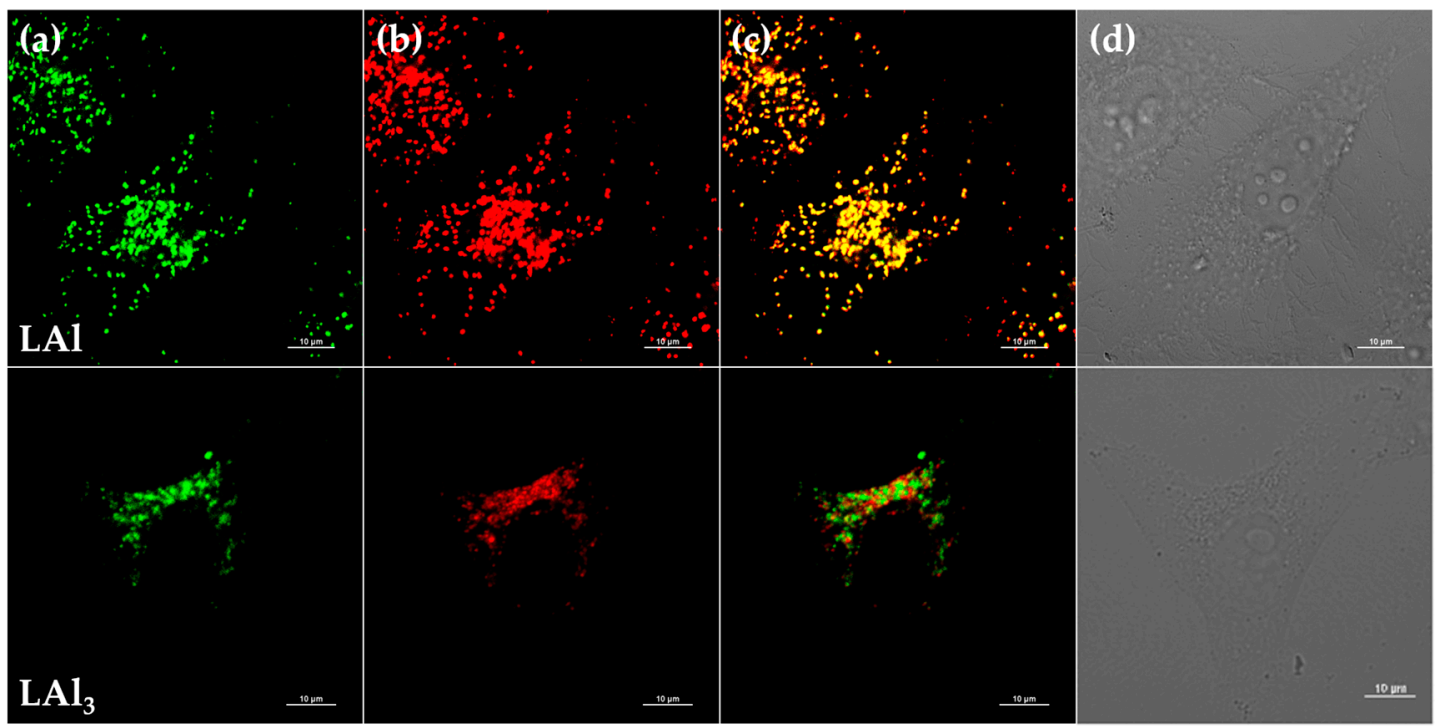

Figure 5. Co-localization studies of the two Al salophen complexes and LysoTracker Red: (a) images of the two compounds indicated; (b) images of LysoTracker Red; (c) merged images of (a,b); (d) Differential interference contrast (DIC). $5 \mu \mathrm{M} \mathrm{Al}$ salophens were incubated with HeLa cells for $12 \mathrm{~h}$ and then $50 \mathrm{~nm}$ LysoTracker Red was incubated with HeLa cells for $20 \mathrm{~min}$. Scale bar: $10 \mu \mathrm{m}$.

Then we examined the subcellular localization of $\mathrm{LAl}$ and $\mathrm{LAl}_{3}$ by co-incubating the complex with a commercial lysosome tracker LysoTracker Red. As shown in Figure 5, the perinuclear punctuate green fluorescence of $\mathrm{LAl}$ and $\mathrm{LAl}_{3}$ overlapped well with the red fluorescence of the lysosome tracker, with Pearson's co-localization coefficients being ca. 0.85 and 0.96 , respectively. This result indicated that $\mathrm{Al}$ salophen complexes were mainly distributed in lysosomal organelles following internalization.

To determine whether the cellular uptake mechanisms of $\mathrm{LAl}$ and $\mathrm{LAl}_{3}$ is energy dependent or independent, we studied the effects of low temperature and ATP depletion in HeLa cells. Incubating cells under low temperature $\left(4^{\circ} \mathrm{C}\right)$ or in the presence of metabolic inhibitors blocks cellular uptake processes requiring energy supply. 2-deoxy-D-glucose and sodium azide, known as inhibitors of oxidative phosphorylation and glycolytic pathway respectively, having been widely used in cellular uptake mechanism studies [43-45]. As shown in Figure 6, no obvious intracellular luminescence of $\mathrm{LAl}$ or $\mathrm{LAl}_{3}$ displayed after incubation under $4{ }^{\circ} \mathrm{C}$, revealing that their uptake was greatly inhibited. When cells were pre-incubated with $10 \mathrm{mM}$ sodium azide or $6 \mathrm{mM}$ 2-deoxy-D-glucose to deplete the cellular ATP level, a smaller but still significant inhibition on the uptake of Al complexes was observed. The above temperature and ATP dependence of the cell uptake suggests that internalization of Al salophen complexes is energy-dependent. Little difference between $\mathrm{LAl}$ and $\mathrm{LAl}_{3}$ is observed. 


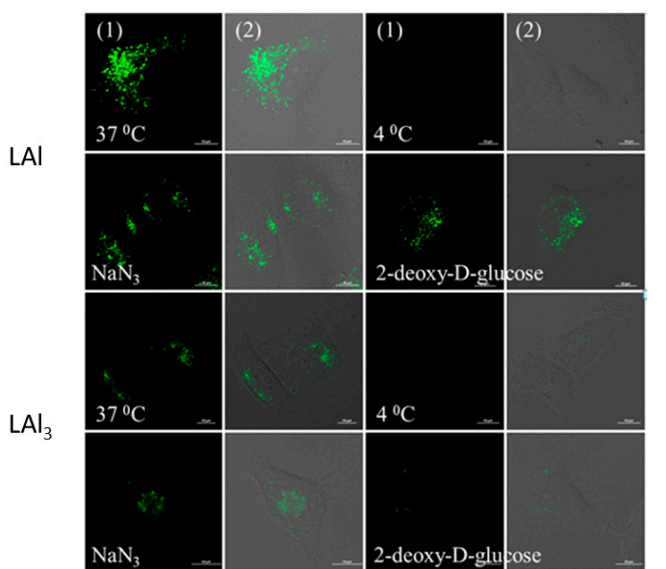

(a)

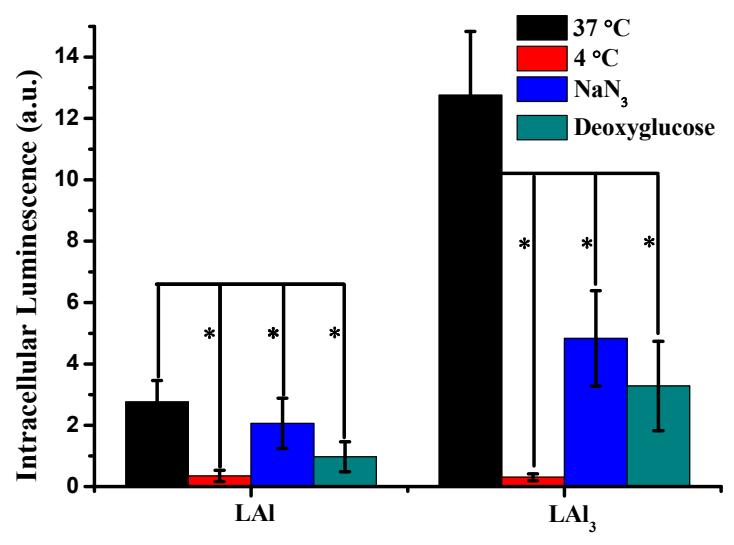

(b)

Figure 6. Cellular uptake of $\mathrm{LAl}$ and $\mathrm{LAl}_{3}$ inhibited at $4{ }^{\circ} \mathrm{C}$ and by depletion of cellular ATP in HeLa cells. (a) Imaging of $\mathrm{LAl}$ and $\mathrm{LAl}_{3}$ which were incubated for $30 \mathrm{~min}$ at $37{ }^{\circ} \mathrm{C}$ or at $4{ }^{\circ} \mathrm{C}$ or after depletion of the cellular ATP pool by $10 \mathrm{mM} \mathrm{NaN}_{3}$ or $6 \mathrm{mM}$ 2-deoxy-D-glucose. (1) Images of the two compounds at the same experimental conditions. (2) Merged images of (1) and Differential interference contrast (DIC). (b) Uptake is expressed as the median of cell fluorescence. Mean \pm SD are indicated. Values significantly $(p<0.005)(n=30)$ different from control (internalization at $\left.37^{\circ} \mathrm{C}\right)$ are marked with asterisk. For depletion of cellular ATP pool, cells were preincubated for $1 \mathrm{~h}$ with $10 \mathrm{mM}$ sodium azide and $6 \mathrm{mM}$ 2-deoxy-D-glucose. a.u., arbitrary unit.

\section{Materials and Methods}

\subsection{General Experimental Information}

All solvents and chemicals were purchased from Alfa Aesar (Haverhill, MA, USA) and J\&K (Beijing, China) and used without further purification, unless specifically mentioned. Cellular imaging trackers were purchased from Invitrogen (Life Technologies, Carlsbad, CA, USA). The ${ }^{1} \mathrm{H}$ NMR spectroscopic measurements were carried out using a Bruker-400 NMR spectrometer (Bruker, Billerica, MA, USA), at $400 \mathrm{MHz}$. Tetramethysilane (TMS) is used as the internal reference. The ${ }^{19} \mathrm{~F}$ NMR spectroscopic measurements were carried out using a Varian-400 NMR (Varian, Palo Alto, CA, USA). Electrospray ionization (ESI) mass spectra were performed on a Fourier transform ion cyclotron resonance mass spectrometer (FT-ICR, Bruker, Billerica, MA, USA). FTIR spectra were taken on a Nicolet iN10 MX Fourier transform infrared spectrometer (ThermoFisher, Carlsbad, CA, USA). Elemental analysis is performed on an Elementar Vario EL CUBE (Elementar, Langenselbold, Germany). The steady-state absorption spectra were attained on an Agilent $8453 \mathrm{UV}$-vis spectrophotometer (Agilent, Santa Clara, CA, USA) in $1 \mathrm{~cm}$ path length quartz cells. Single-photon luminescence spectra were recorded using fluorescence lifetime and steady state spectrophotometer (Edinburgh Instrument FLS920, Livingston, UK). Quantum yields of one photon emission of all the synthesized compounds were measured relative to the fluorescence of quinine sulfate in $0.1 \mathrm{~N} \mathrm{H}_{2} \mathrm{SO}_{4}$. Confocal fluorescent images of living cells were performed using Nikon A1R-si laser scanning confocal microscope (Nikon, Tokyo, Japan), equipped with the laser of $405 \mathrm{~nm}$.

\subsection{Synthesis and Characterization}

LAl was synthesized according to the reported methods. First, we synthesized the mononuclear salophen ligand. Salicylaldehyde $(10 \mathrm{mmol}, 10.4 \mathrm{~mL})$ and o-phenylenediamine (5 mmol, $540.7 \mathrm{mg}$ ) were refluxing in $20 \mathrm{~mL}$ ethanol for $16 \mathrm{~h}$, after cooling to the room temperature, the mixture was filtered to achieve the ligand $(1.3 \mathrm{~g}$, yield $85 \%)$. The ligand $(158.2 \mathrm{mg}, 0.5 \mathrm{mmol})$ and aluminum chloride $(68 \mathrm{mg}$, $0.51 \mathrm{mmol}$ ) were refluxing in $20 \mathrm{~mL}$ acetonitrile solution for $16 \mathrm{~h}$, then filtered and the precipitate was wash by $\mathrm{CH}_{3} \mathrm{CN}$ to afford the aimed product (147 mg, yield: $78 \%$ ). ${ }^{1} \mathrm{H}$ NMR (400 MHz, DMSO-d6): 
$\delta(\mathrm{ppm}) 9.29(2 \mathrm{H}, \mathrm{s}), 8.22-8.07(2 \mathrm{H}, \mathrm{m}), 7.68(2 \mathrm{H}, \mathrm{dd}, \mathrm{J} 7.8,1.6), 7.61-7.45(4 \mathrm{H}, \mathrm{m}), 6.97(2 \mathrm{H}, \mathrm{d}, \mathrm{J} 8.4)$, 6.85 (2H, t, J 7.4). HR MS (ESI ${ }^{+}$, DMSO, FT-ICR): $m / z$ calcd. For $\mathrm{C}_{20} \mathrm{H}_{14} \mathrm{AlN}_{2} \mathrm{O}_{2}\left([\mathrm{M}-\mathrm{Cl}]^{+}\right) 341.0866$, found 341.0865. FTIR (KBr pellete, $\mathrm{cm}^{-1}$ ): $1625(\mathrm{C}=\mathrm{N}), 1546$ ( $\left.\mathrm{Ar} \mathrm{C}=\mathrm{C}\right), 1473(\mathrm{Ar} \mathrm{C}=\mathrm{C}), 1196(\mathrm{C}-\mathrm{O})$.

$\mathrm{LAl}_{3}$ : Cryptand-type salophen ligand was prepared according to the procedure reported by $\mathrm{T}$. Nabeshima [41]. A mixture of $137.5 \mathrm{mg}(0.14 \mathrm{mmol})$ of trinuclear salophen free base ligand and $58 \mathrm{mg}$ $(0.44 \mathrm{mmol})$ anhydrous aluminum chloride was dissolved in acetonitrile $(20.0 \mathrm{~mL})$ the solution was refluxed overnight. After cooling to the room temperature, the mixture was filtered and the solid was washed in turn by acetonitrile and diethyl ether, $1 \mathrm{~mL}$ each time, to remove the extra aluminum salts. After dried under reduced pressure, the product was obtained as yellow powder $(110 \mathrm{mg}$, 68\%). ${ }^{1} \mathrm{H}$ NMR (400 MHz, DMSO-d6): $\delta$ (ppm) $9.32(6 \mathrm{H}, \mathrm{s}), 8.27(2 \mathrm{H}, \mathrm{s}), 8.14(6 \mathrm{H}, \mathrm{dd}, \mathrm{J} 5.9,3.5)$, $7.52(12 \mathrm{H}, \mathrm{m}, \mathrm{J} 6.7), 7.07(6 \mathrm{H}, \mathrm{dd}, \mathrm{J} 7.0), 6.71(6 \mathrm{H}, \mathrm{t}) . \quad \mathrm{HR}$ MS (ESI $\left.{ }^{+}, \mathrm{DMSO}, \mathrm{FT}-\mathrm{ICR}\right): \mathrm{m} / \mathrm{z}$ calcd. For $\mathrm{C}_{62} \mathrm{H}_{38} \mathrm{Al}_{3} \mathrm{Cl}_{2} \mathrm{~N}_{6} \mathrm{O}_{6}\left(\left[\mathrm{M}-\mathrm{Cl}+\mathrm{DMSO}^{+}\right)\right.$1191.1810, found 1191.1832. FTIR (KBr pellete, $\left.\mathrm{cm}^{-1}\right)$ : $1620(\mathrm{C}=\mathrm{N}), 1551$ (Ar $\mathrm{C}=\mathrm{C}), 1442(\mathrm{Ar} \mathrm{C}=\mathrm{C}), 1393$ (Ar $\mathrm{C}=\mathrm{C}), 1199$ (C-O). Anal. Calcd for $\mathrm{C}_{62} \mathrm{H}_{38} \mathrm{~N}_{6} \mathrm{O}_{6} \mathrm{Al}_{3} \mathrm{Cl}_{3} \cdot 33 \mathrm{H}_{2} \mathrm{O}: \mathrm{C}, 42.68 ; \mathrm{H}, 6.01 ; \mathrm{N}, 4.82$. Found: $\mathrm{C}, 42.55 ; \mathrm{H}, 4.60 ; \mathrm{N}, 7.72$. Anal. Calcd for $\mathrm{C}_{62} \mathrm{H}_{38} \mathrm{Al}_{3} \mathrm{Cl}_{3} \mathrm{~N}_{6} \mathrm{O}_{6} \cdot \mathrm{CH}_{3} \mathrm{CN} \cdot 12 \mathrm{H}_{2} \mathrm{O}: \mathrm{C}, 54.61 ; \mathrm{H}, 4.65 ; \mathrm{N}, 6.97$. Found: $\mathrm{C}, 54.72 ; \mathrm{H}, 4.15 ; \mathrm{N}, 6.94$.

$\mathrm{LAl}_{3}-\mathrm{F}$ : A mixture of $45.9 \mathrm{mg}(0.040 \mathrm{~mol})$ of $\mathrm{LAl}_{3}$ and $4.6 \mathrm{mg}(0.124 \mathrm{~mol}) \mathrm{NH}_{4} \mathrm{~F}$ was dissolved in DMSO $(10.0 \mathrm{~mL})$, the solution stirred overnight at room temperature, then reduced pressure distillation. The precipitate was washed in turn by $\mathrm{MeOH}$ and diethyl ether, $1 \mathrm{~mL}$ each time, to remove the extra salts. After dried under reduced pressure, the product was obtained as yellow powder $(30 \mathrm{mg}$, 68\%). ${ }^{1} \mathrm{H}$ NMR (400 MHz, DMSO-d6): $\delta$ (ppm) $8.34(6 \mathrm{H}, \mathrm{s}), 7.34-7.17(8 \mathrm{H}, \mathrm{m}), 7.05-6.77(12 \mathrm{H}, \mathrm{m})$, $6.30\left(6 \mathrm{H}, \mathrm{dd}, \mathrm{J}\right.$ 6.0), $6.12\left(6 \mathrm{H}, \mathrm{t}, \mathrm{J}\right.$ 7.6). HR MS (ESI ${ }^{+}$, DMSO, FT-ICR): $\mathrm{m} / z$ calcd. For $\mathrm{C}_{62} \mathrm{H}_{38} \mathrm{Al}_{3} \mathrm{Cl}_{2} \mathrm{~N}_{6} \mathrm{O}_{6}$ $\left([\mathrm{M}-\mathrm{F}]^{+}\right)$1081.2262, found 1081.2255.

\subsection{Photophysical Properties}

Quantum yields of emission of synthesized two compounds were measured with quinine sulfate (dissolved in $0.1 \mathrm{~N} \mathrm{H}_{2} \mathrm{SO}_{4}$ ) as reference. The fluorescence measurements were performed in $1 \mathrm{~cm}$ quartz cells with $1 \mu \mathrm{M}$ compound in DMSO on a fluorescence lifetime and steady state spectrophotometer (Edinburgh Instrument FLS920) equipped $450 \mathrm{~W}$ Xenon light, slits $2.5 \times 2.5$. The values of fluorescence quantum yield, $\Phi$ (sample), were calculated according to the equation

$$
\Phi_{\text {sample }}=\Phi_{\text {ref }} \frac{O D_{r e f} \cdot I_{\text {sample }} \cdot d_{\text {sample }}^{2}}{O D_{\text {sample }} \cdot I_{r e f} \cdot d_{r e f}^{2}}
$$

$\Phi_{\text {ref: }}$ The values of fluorescence quantum yield of the reference.

I: integrated emission intensity.

$O D$ : optical density at the excitation wavelength.

$d$ : the refractive index of solvents. $d_{\mathrm{DMSO}}=1.478, d_{\mathrm{H} 2 \mathrm{O}}=1.333$.

\subsection{Determination of the Octanol-Water Partition Coefficients (Log P)}

Equal volume $(200 \mathrm{~mL})$ of $\mathrm{N}$-octanol and water were thoroughly mixed by an oscillator and separated after $24 \mathrm{~h}$. Two compounds ( $1 \mathrm{mg}$ each) were then dissolved in $40 \mathrm{~mL}$ of the separated $\mathrm{N}$-octanol and the solution was allowed to equilibrate for further $24 \mathrm{~h}$. The extinction coefficient was then calculated and $40 \mathrm{~mL}$ of water (previously separated from the mixture) was added. The new octanol-water system was allowed to equilibrate for additional $24 \mathrm{~h}$. After separating, both fractions were analyzed by UV-vis spectra. The $\log P$ values were calculated by

$$
\log P=\log \frac{C_{\text {octanol }}}{C_{\text {water }}}
$$


where $C_{\text {octanol }}$ and $C_{\text {water }}$ refer to the concentration of two compounds in the $N$-octanol and water, respectively.

\subsection{Live Cell Imaging}

All cells were incubated in complete medium (Dulbecco's modified Eagle's medium, supplemented with $10 \%$ fetal bovine serum (FBS) and $1 \%$ penicillin-streptomycin) at $37{ }^{\circ} \mathrm{C}$ in atmosphere containing $5 \% \mathrm{CO}_{2}$. For imaging, HeLa cells were grown in poly-D-lysine-coated dishes and incubated in $2 \mathrm{~mL}$ of complete medium for $24 \mathrm{~h}$. Cells were washed with PBS, and stocked dyes ( $1 \mathrm{mM}$ in DMSO) were added to obtain a final concentration of $5 \mu \mathrm{M}$. The treated cells were incubated for $12 \mathrm{~h}$ at $37^{\circ} \mathrm{C}$. A few minutes prior to confocal imaging cells were washed twice with PBS. A confocal laser scanning microscope (A1R-si, Nikon, Tokyo, Japan) was used to obtain images. Cells were imaged via the fluorescence mode with a $60 \times$ immersion lens with the following parameters: laser power $100 \%$, pinhole 4.0 a.u., excitation wavelength $405 \mathrm{~nm}$, detector slit 500-530 nm, resolution $1024 \times 1024$, and a scan speed 0.5 frames per second.

HeLa cells were placed onto $0.1 \mathrm{mM}$ poly-D-lysine coated glasses in complete media and the cells were incubated for $24 \mathrm{~h}$. A stock solution of salophen complexes in chromatographic grade, anhydrous DMSO was prepared as $1 \mathrm{mM}$. The solution was diluted to a final concentration of $5 \mu \mathrm{M}$ by complete growth medium and coincubated with HeLa cells for $12 \mathrm{~h}$. Stock solutions of LysoTracker Red was prepared as $1 \mathrm{mM}$, and the stock solution was diluted to the working concentrations in complete medium $(1 \mu \mathrm{M})$. After incubating for half an hour, cells were washed with PBS buffer twice before confocal experiments. Differential interference contrast (DIC) and fluorescent images were processed and analyzed using Image J (version 1.8.0).

For the cellular uptake experiment, the cells were incubated with $\mathrm{LAl}$ or $\mathrm{LAl}_{3}$ at $37{ }^{\circ} \mathrm{C}$ for $2 \mathrm{~h}$, while cells at $4{ }^{\circ} \mathrm{C}$ were treated with precooled complete growth medium containing $5 \mu \mathrm{M} \mathrm{LAl}$ or $\mathrm{LAl}_{3}$, respectively. For the ATP depletion groups, HeLa cells were preincubated with $10 \mathrm{mM}$ sodium azide or $6 \mathrm{mM}$ 2-deoxy-D-glucose for $1 \mathrm{~h}$, then treated with $10 \mathrm{mM}$ sodium azide or $6 \mathrm{mM}$ 2-deoxy-D-glucose complete growth medium containing $5 \mu \mathrm{M} \mathrm{LAl}$ or $\mathrm{LAl}_{3}$ for $2 \mathrm{~h}$.

Hela cells were seeded in flat-bottomed 96-well plates, $10^{4}$ cells per well, with $200 \mu \mathrm{L}$ complete culture media in the dark for $24 \mathrm{~h}$. After being washed with PBS three times $(200 \mu \mathrm{L} \times 3)$, the cells were incubated with $5 \mu \mathrm{M}$ concentrations of the studied salophens for another $24 \mathrm{~h}$ in the dark while untreated-cells and wells containing no cells are set as the controls. HeLa cells were then washed with PBS three times $(200 \mu \mathrm{L} \times 3) .10 \mu \mathrm{L}$ Cell Counting Kit-8 (CCK-8) solution and $90 \mu \mathrm{L}$ PBS were added per well. After $2 \mathrm{~h}$, the absorbance at $450 \mathrm{~nm}$ was read by 96 -well plate reader. The viability of Hela cells was calculated by

$$
\mathrm{CV}=\frac{A_{s}-A_{b}}{A_{c}-A_{b}} \times 100 \%
$$

CV stands for the viability of cells, $A_{s}, A_{c}$, and $A_{b}$ stand for the absorbance of cells containing 2-Glu, cell control ( $0 \mu \mathrm{M}$ 2-Glu), and blank control (wells containing neither cells nor 2-Glu).

\section{Conclusions}

In summary, we reported the synthesis and characterization of the cryptand-type Al salophen complex $\mathrm{LAl}_{3}$. The cryptand-type structure was confirmed by the X-ray crystal diffraction. $\mathrm{LAl}_{3}$ showed green fluorescence emission similar to the mononuclear $\mathrm{LAl}$, and can be internalized into HeLa cells by energy-dependent pathways. It could be used as lysosome localized fluorescent probes for live cell imaging, which was superior to their $\mathrm{Zn}$ analogues.

Supplementary Materials: The Supplementary materials including ${ }^{1} \mathrm{H}$ NMR and HRMS spectra of the three complexes are available online at www.mdpi.com/2304-6740/6/1/20/s1.

Acknowledgments: We acknowledge financial support from the National Key Basic Research Support Foundation of China (Grant 2015CB856301) and the National Scientific Foundation of China (Grants 21571007, 21271013, 21321001, 81570791). 
Author Contributions: Jun-Long Zhang and Yanli Shang conceived and designed the experiments; Jing Lai, Juan Tang and Hao-Yan Yin performed the experiments as well as analyzed the data; Hao-Yan Yin and Jing Lai wrote the paper.

Conflicts of Interest: The authors declare no conflict of interest.

\section{References}

1. Cozzi, P.G. Metal-Salen Schiff Base Complexes in Catalysis: Practical Aspects. Chem. Soc. Rev. 2004, 33, 410-421. [CrossRef] [PubMed]

2. Venkataramanan, N.S.; Kuppuraj, G.; Rajagopal, S. Metal-Salen Complexes as Efficient Catalysts for the Oxygenation of Heteroatom Containing Organic Compounds-Synthetic and Mechanistic Aspects. Coord. Chem. Rev. 2005, 249, 1249-1268. [CrossRef]

3. Baleizão, C.; Garcia, H. Chiral Salen Complexes: An Overview to Recoverable and Reusable Homogeneous and Heterogeneous Catalysts. Chem. Rev. 2006, 106, 3987-4043. [CrossRef] [PubMed]

4. Gupta, K.C.; Sutar, A.K. Catalytic Activities of Schiff Base Transition Metal Complexes. Coord. Chem. Rev. 2008, 252, 1420-1450. [CrossRef]

5. Miyasaka, H.; Saitoh, A.; Abe, S. Magnetic Assemblies Based on Mn(III) Salen Analogues. Coord. Chem. Rev. 2007, 251, 2622-2664. [CrossRef]

6. Wezenberg, S.J.; Kleij, A.W. Material Applications for Salen Frameworks. Angew. Chem. Int. Ed. 2008, 47, 2354-2364. [CrossRef] [PubMed]

7. Kleij, A.W. Zinc-Centred Salen Complexes: Versatile and Accessible Supramolecular Building Motifs. Dalton Trans. 2009, 4635-4639. [CrossRef] [PubMed]

8. Erxleben, A. Transition Metal Salen Complexes in Bioinorganic and Medicinal Chemistry. Inorg. Chim. Acta 2017. [CrossRef]

9. Yin, H.-Y.; Tang, J.; Zhang, J.-L. Introducing Metallosalens into Biological Studies: The Renaissance of Traditional Coordination Complexes. Eur. J. Inorg. Chem. 2017, 5085-5093. [CrossRef]

10. Giannicchi, I.; Brissos, R.; Ramos, D.; de Lapuente, J.; Lima, J.C.; Cort, A.D.; Rodriguez, L. Substituent Effects on the Biological Properties of Zn-Salophen Complexes. Inorg. Chem. 2013, 52, 9245-9253. [CrossRef] [PubMed]

11. Reed, J.E.; Arnal, A.A.; Neidle, S.; Vilar, R. Stabilization of G-Quadruplex DNA and Inhibition of Telomerase Activity by Square-Planar Nickel(II) Complexes. J. Am. Chem. Soc. 2006, 128, 5992-5993. [CrossRef] [PubMed]

12. Arola-Arnal, A.; Benet-Buchholz, J.; Neidle, S.; Vilar, R. Effects of Metal Coordination Geometry on Stabilization of Human Telomeric Quadruplex DNA by Square-Planar and Square-Pyramidal Metal Complexes. Inorg. Chem. 2008, 47, 11910-11919. [CrossRef] [PubMed]

13. Campbell, N.H.; Karim, N.H.; Parkinson, G.N.; Gunaratnam, M.; Petrucci, V.; Todd, A.K.; Vilar, R.; Neidle, S. Molecular Basis of Structure-Activity Relationships between Salphen Metal Complexes and Human Telomeric DNA Quadruplexes. J. Med. Chem. 2012, 55, 209-222. [CrossRef] [PubMed]

14. Abd Karim, N.H.; Mendoza, O.; Shivalingam, A.; Thompson, A.J.; Ghosh, S.; Kuimova, M.K.; Vilar, R. Salphen Metal Complexes as Tunable G-Quadruplex Binders and Optical Probes. RSC Adv. 2014, 4, 3355-3363. [CrossRef]

15. Zhou, C.Q.; Liao, T.C.; Li, Z.Q.; Gonzalez-Garcia, J.; Reynolds, M.; Zou, M.; Vilar, R. Dinickel-Salphen Complexes as Binders of Human Telomeric Dimeric G-Quadruplexes. Chem. Eur. J. 2017, 23, 4713-4722. [CrossRef] [PubMed]

16. Bandeira, S.; Gonzalez-Garcia, J.; Pensa, E.; Albrecht, T.; Vilar, R. A Redox-Activated G-Quadruplex DNA Binder Based on a Platinum(IV)-Salphen Complex. Angew. Chem. Int. Ed. 2018, 57, 310-313. [CrossRef] [PubMed]

17. Hai, Y.; Chen, J.J.; Zhao, P.; Lv, H.; Yu, Y.; Xu, P.; Zhang, J.-L. Luminescent Zinc Salen Complexes as Single and Two-Photon Fluorescence Subcellular Imaging Probes. Chem. Commun. 2011, 47, 2435-2437. [CrossRef] [PubMed]

18. Jing, J.; Chen, J.-J.; Hai, Y.; Zhan, J.; Xu, P.; Zhang, J.-L. Rational Design of Znsalen as a Single and Two Photon Activatable Fluorophore in Living Cells. Chem. Sci. 2012, 3, 3315-3320. [CrossRef] 
19. Chen, J.J.; Jing, J.; Chang, H.; Rong, Y.; Hai, Y.; Tang, J.; Zhang, J.L.; Xu, P. A Sensitive and Quantitative Autolysosome Probe for Detecting Autophagic Activity in Live and Prestained Fixed Cells. Autophagy 2013, 9, 894-904. [CrossRef] [PubMed]

20. Jing, J.; Zhang, J.-L. Combining Myeloperoxidase (Mpo) with Fluorogenic Znsalen to Detect Lysosomal Hydrogen Peroxide in Live Cells. Chem. Sci. 2013, 4, 2947-2952. [CrossRef]

21. Xie, D.; Jing, J.; Cai, Y.-B.; Tang, J.; Chen, J.-J.; Zhang, J.-L. Construction of an Orthogonal Znsalen/Salophen Library as a Colour Palette for One- and Two-Photon Live Cell Imaging. Chem. Sci. 2014, 5, 2318-2327. [CrossRef]

22. Tang, J.; Zhang, M.; Yin, H.Y.; Jing, J.; Xie, D.; Xu, P.; Zhang, J.L. A Photoactivatable Znsalen Complex for Super-Resolution Imaging of Mitochondria in Living Cells. Chem. Commun. 2016, 52, 11583-11586. [CrossRef] [PubMed]

23. Tang, J.; Zhang, Y.; Yin, H.Y.; Xu, G.; Zhang, J.L. Precise Labeling and Tracking of Lipid Droplets in Adipocytes Using a Luminescent Znsalen Complex. Chem. Asian J. 2017, 12, 2533-2538. [CrossRef] [PubMed]

24. Consiglio, G.; Failla, S.; Finocchiaro, P.; Oliveri, I.P.; Purrello, R.; di Bella, S. Supramolecular Aggregation/Deaggregation in Amphiphilic Dipolar Schiff-Base Zinc(II) Complexes. Inorg. Chem. 2010, 49, 5134-5142. [CrossRef] [PubMed]

25. Hui, J.K.; MacLachlan, M.J. Fibrous Aggregates from Dinuclear Zinc(II) Salphen Complexes. Dalton Trans. 2010, 39, 7310-7319. [CrossRef] [PubMed]

26. Cai, Y.B.; Zhan, J.; Hai, Y.; Zhang, J.L. Molecular Assembly Directed by Metal-Aromatic Interactions: Control of the Aggregation and Photophysical Properties of Zn-Salen Complexes by Aromatic Mercuration. Chem. Eur. J. 2012, 18, 4242-4249. [CrossRef] [PubMed]

27. Consiglio, G.; Failla, S.; Finocchiaro, P.; Oliveri, I.P.; di Bella, S. Aggregation Properties of Bis(Salicylaldiminato)Zinc(Ii) Schiff-Base Complexes and Their Lewis Acidic Character. Dalton Trans. 2012, 41, 387-395. [CrossRef] [PubMed]

28. Consiglio, G.; Oliveri, I.P.; Punzo, F.; Thompson, A.L.; di Bella, S.; Failla, S. Structure and Aggregation Properties of a Schiff-Base Zinc(Ii) Complex Derived from Cis-1,2-Diaminocyclohexane. Dalton Trans. 2015, 44, 13040-13048. [CrossRef] [PubMed]

29. Puglisi, R.; Ballistreri, F.P.; Gangemi, C.M.A.; Toscano, R.M.; Tomaselli, G.A.; Pappalardo, A.; Sfrazzetto, G.T. Chiral Zn-Salen Complexes: A New Class of Fluorescent Receptors for Enantiodiscrimination of Chiral Amines. New J. Chem. 2017, 41, 911-915. [CrossRef]

30. Tang, J.; Cai, Y.-B.; Jing, J.; Zhang, J.-L. Unravelling the Correlation between Metal Induced Aggregation and Cellular Uptake/Subcellular Localization of Znsalen: An Overlooked Rule for Design of Luminescent Metal Probes. Chem. Sci. 2015, 6, 2389-2397. [CrossRef] [PubMed]

31. Tang, J.; Xie, D.; Yin, H.Y.; Jing, J.; Zhang, J.L. Cationic Sulfonium Functionalization Renders Znsalens with High Fluorescence, Good Water Solubility and Tunable Cell-Permeability. Org. Biomol. Chem. 2016, 14, 3360-3368. [CrossRef] [PubMed]

32. Lai, J.; Ke, X.-S.; Tang, J.; Zhang, J.-L. Tris(Znsalen) Cryptand Minimizes Znsalen Aggregation Arising from Intermolecular Zn ‥O Interaction. Chin. Chem. Lett. 2015, 26, 937-941. [CrossRef]

33. Yin, H.-Y.; Tang, J.; Zhang, J.-L. Luminescent Metal Salen Complex as Intracellular Microviscosity Fluorescent Sensor. Sci. Sin. Chim. 2016, 47, 267-276.

34. Tang, J.; Yin, H.Y.; Zhang, J.L. A Luminescent Aluminium Salen Complex Allows for Monitoring Dynamic Vesicle Trafficking from the Golgi Apparatus to Lysosomes in Living Cells. Chem. Sci. 2018. [CrossRef]

35. Darensbourg, D.J.; Billodeaux, D.R. Aluminum Salen Complexes and Tetrabutylammonium Salts: A Binary Catalytic System for Production of Polycarbonates from $\mathrm{CO}_{2}$ and Cyclohexene Oxide. Inorg. Chem. 2005, 44, 1433-1442. [CrossRef] [PubMed]

36. Reich, B.J.; Greenwald, E.E.; Justice, A.K.; Beckstead, B.T.; Reibenspies, J.H.; North, S.W.; Miller, S.A. Ene-Diamine Versus Imine-Amine Isomeric Preferences. J. Org. Chem. 2005, 70, 8409-8416. [CrossRef] [PubMed]

37. Bi, W.; Wei, T.; Lü, X.; Hui, Y.; Song, J.; Zhao, S.; Wong, W.; Jones, R.A. Hetero-Trinuclear near-Infrared (Nir) Luminescent $\mathrm{Zn}_{2}$ Ln Complexes from Salen-Type Schiff-Base Ligands. New J. Chem. 2009, 33, 2326-2334. [CrossRef]

38. Suh, H.; Song, S.; Ahn, S.; Kim, T.; Kim, B.; Chang, T. Greenhouse Gas Conversion by Homogeneous Salen Catalyst Systems under Very Mild Reaction Condition. J. Korean Chem. Soc. 2013, 57, 525-528. [CrossRef] 
39. Cheng, J.; Ma, X.; Zhang, Y.; Liu, J.; Zhou, X.; Xiang, H. Optical Chemosensors Based on Transmetalation of Salen-Based Schiff Base Complexes. Inorg. Chem. 2014, 53, 3210-3219. [CrossRef] [PubMed]

40. Nemec, I.; Herchel, R.; Silha, T.; Travnicek, Z. Towards a Better Understanding of Magnetic Exchange Mediated by Hydrogen Bonds in Mn(III)/Fe(III) Salen-Type Supramolecular Dimers. Dalton Trans. 2014, 43, 15602-15616. [CrossRef] [PubMed]

41. Akine, S.; Piao, S.; Miyashita, M.; Nabeshima, T. Cage-Like Tris(Salen)-Type Metallocryptand for Cooperative Guest Recognition. Tetrahedron Lett. 2013, 54, 6541-6544. [CrossRef]

42. Leo, A.; Hansch, C.; Elkins, D. Partition Coefficients and Their Uses. Chem. Rev. 1971, 71, 525-616. [CrossRef]

43. Bacallao, R.; Garfinkel, A.; Monke, S.; Zampighi, G.; Mandel, L.J. Atp Depletion: A Novel Method to Study Junctional Properties in Epithelial Tissues. J. Cell Sci. 1994, 3301-3313.

44. Sorensen, M.; Sehested, M.; Jensen, P.B. Effect of Cellular Atp Depletion on Topoisomerase Ii Poisons. Abrogation of Cleavable-Complex Formation by Etoposide but Not by Amsacrine. Mol. Pharmacol. 1999, 55, 424-431. [PubMed]

45. Komor, A.C.; Barton, J.K. The Path for Metal Complexes to a DNA Target. Chem. Commun. 2013, 49, 3617-3630. [CrossRef] [PubMed]

(C) 2018 by the authors. Licensee MDPI, Basel, Switzerland. This article is an open access article distributed under the terms and conditions of the Creative Commons Attribution (CC BY) license (http://creativecommons.org/licenses/by/4.0/). 